\title{
Margaret McCartney: Stop disciplining us for being ill
}

\author{
Margaret McCartney, general practitioner
}

Glasgow

Doctors, unsurprisingly, get sick. The UK General Medical Council says, "If you have a health condition or have a problem with alcohol or drugs that may put patients at risk, you need to let us know so that we can ensure that patients are protected."

One doctor told me that she'd told the GMC that she thought she could put patients at risk if she had a relapse of her chronic mental illness. This led to a fitness to practise process, even though she'd taken independent advice, spent time off work as advised, and returned when she'd recovered. She felt like a criminal, subjected to an adversarial process.

The GMC told me, "Doctors certainly do not always have to tell us if they have a health condition. If they have taken the appropriate steps to manage their condition and it does not affect their ability to care for patients, then we don't need to know about it."

So, should all doctors who've had to take time off work because of flu-which did affect their ability to care for patients-tell the GMC? Ill doctors who are not taking their own doctors' advice about working should undergo separate health assessment, not disciplinary proceedings.

The GMC's other advice is clear and reasonable, if contradictory: "If your judgement or performance could be affected by a condition or its treatment, you must consult a suitably qualified colleague. You must ask for and follow their advice about investigations, treatment and changes to your practice that they consider necessary."

Appraisal seems prone to confusion with occupational health assessment. One doctor told me that his appraiser had told him he could be "at risk" if he didn't fully disclose his health problems. A recent article said that doctors should have "full, open and hopefully supportive discussion" because "denying or concealing ill health" is the "action of an "unacceptable GP.",
This is rot: an appraisal expert, Susi Caesar, told me, "It is not necessary or appropriate for GPs to give details about their own health to their appraiser unless they wish to do so. There should certainly be no implication that they should . . . independent advice is best done through their own GP, or an occupational health service, not an appraiser." Amen to that, especially because appraisal documentation is not truly confidential. ${ }^{4}$ The many doctors who have died by suicide while under the GMC's investigations should be a stark warning. ${ }^{5}$ Louis Appleby, a psychiatry professor, is reviewing how the GMC's guidance works. Let's hope that we move to a system where ill doctors, who seek and take the advice of their own physicians, don't come anywhere near its sight line. Let's stop disciplining doctors for being ill.

Competing interests: See www.bmj.com/about-bmj/freelancecontributors/margaret-mccartney.

Provenance and peer review: Commissioned; not externally peer reviewed.

1 General Medical Council. Your health matters. www.gmc-uk.org/concerns/11543.asp. General Medical Council. Supporting information for appraisal and revalidation. Mar 2012 www.gmc-uk.org/static/documents/content/RT_Supporting_information_for_appraisal and_revalidation__DC5485.pdf_55024594.pdf.

3 Clearing common hurdles of revalidation. Pulse 2016 Mar 2. Available at www.pulsetoday. co.uk/.

4 Royal College of General Practitioners. The principles of GP appraisal for revalidation. Sep 2014. www.rcgp.org.uk/courses-and-events/ /media/Files/Revalidation-and-CPD/ CPD-Credits-and-Appraisal/The-Principles-of-GP-Appraisal-for-Revalidation-2014.ashx

5 General Medical Council. Doctors who commit suicide while under GMC fitness to practise investigation: internal review. 14 Dec 2014.www.gmc-uk.org/Internal_review_into_suicide_ in_FTP_processes.pdf_59088696.pdf.

Published by the BMJ Publishing Group Limited. For permission to use (where not already granted under a licence) please go to http://group.bmj.com/group/rights-licensing/ permissions 